\title{
Evidence for a Potential Role of Metallothioneins in Inflammatory Bowel Diseases
}

\author{
Anouk Waeytens, Martine De Vos, and Debby Laukens \\ Department of Gastroenterology, Ghent University, De Pintelaan 185, 9000 Gent, Belgium \\ Correspondence should be addressed to Anouk Waeytens, anouk.waeytens@ugent.be \\ Received 26 January 2009; Accepted 3 July 2009 \\ Recommended by Donna-Marie McCafferty
}

Inflammatory bowel diseases (IBDs) are a group of chronic, relapsing, immune-mediated disorders of the intestine, including Crohn's disease and ulcerative colitis. Recent studies underscore the importance of the damaged epithelial barrier and the dysregulated innate immune system in their pathogenesis. Metallothioneins (MTs) are a family of small proteins with a high and conserved cysteine content that are rapidly upregulated in response to an inflammatory stimulus. Herein, we review the current knowledge regarding the expression and potential role of MTs in IBD. MTs exert a central position in zinc homeostasis, modulate the activation of the transcription factor nuclear factor (NF)- $\kappa \mathrm{B}$, and serve as antioxidants. In addition, MTs could be involved in IBD through their antiapoptotic effects or through specific immunomodulating extracellular effects. Reports on MT expression in IBD are contradictory but clearly demonstrate a deviant MT expression supporting the idea that these aberrations in IBD require further clarification.

Copyright (C) 2009 Anouk Waeytens et al. This is an open access article distributed under the Creative Commons Attribution License, which permits unrestricted use, distribution, and reproduction in any medium, provided the original work is properly cited.

\section{Introduction}

Metallothioneins (MTs) are a superfamily of small proteins that are present in virtually every living organism [1]. A typical feature is their highly conserved number and position of cysteine residues, enabling them to incorporate monovalent and divalent metal atoms and to reduce reactive oxygen and nitrogen species [2]. So far, 19 human isoforms have been cloned, 11 of which are known to be functional (i.e., MT1A, MT1B, MT1E, MT1F, MT1G, MT1H, MT1M, MT1X, MT2A, MT3, and MT4) [3]. The majority of these genes cluster together on a single locus on chromosome 16 (16q13) [4]. Heterogeneity of isoforms results from posttranslational modifications and/or variations in metal composition [5]. The most widely expressed isoforms are MT-1 and MT-2, and they are highly inducible [3]. On the basal level, MT-2 appears to be expressed more than the MT1 isoforms. The MT-3 and MT-4 proteins are constitutively expressed and are found mainly in the brain [6], kidney [7], and reproductive organs [8] (MT-3) and in certain squamous epithelia [9] (MT-4). Human MT isoforms are regulated independently of each other and can be induced by metals, stress hormones, cytokines, reactive oxygen species (ROS), and chemicals [3]. In mice, the situation is more simple. Only four functional murine MT genes are known (MT1, MT2, MT3, and MT4), and the MT1 and MT2 isoforms are coordinately regulated $[5,10]$.

\section{MT Regulation in Inflammation}

One of the most striking observations that link MTs to inflammation is their rapid upregulation in response to a variety of stresses including inflammation. Hepatic expression of MTs is dramatically elevated in response to bacterial infection, an effect mediated by endotoxin (lipopolysaccharide-LPS). This observation has lead to the classification of MTs as acute phase proteins. LPS induction of MT gene expression in mice occurred in each organ examined (liver, kidney, pancreas, intestine, lung, heart, brain, ovary, uterus, and spleen) [11]. This induction by LPS was shown to be mediated by several proinflammatory cytokines, including interleukin (IL)-1, IL-6, tumor necrosis factor (TNF)- $\alpha$, interferon (IFN) $-\gamma[11]$, nitric oxide (NO) 
[12] as well as the stress hormones glucocorticoids [13]. These factors have been shown to be able to upregulate MTs independently of LPS. They seem to act synergistically and result in different levels of MT expression, depending on the tissue and the combination of factors [11, 14-16]. ROS generated during the inflammatory response may activate MT expression through multiple pathways, including directly by stimulating an antioxidant response element and specific metal response elements in the promoter region as well as indirectly by events associated with second-messenger protein kinase pathways $[17,18]$. During radiation injury to the small intestine, which implicates ROS and leads to acute inflammation, metallothioneins were induced [19]. All these data illustrate that MT regulation in inflammation is a rapid but complex process with different results in different tissues. One constant, however, is that MT induction by inflammatory mediators seems to be conditional upon the presence of zinc [5].

\section{MT Functions Relevant in Inflammation and Possibly in Inflammatory Bowel Diseases (Figure 1)}

The first function of MTs that was put forward as playing a role in inflammation was their central position in zinc homeostasis, redistributing the intracellular zinc pool. In that way, MTs can have two opposite roles: they can either increase the intracellular zinc pool, thereby facilitating metabolic processes during the acute phase response or sequester zinc to allow maximal activity of enzymes which would be otherwise inhibited by zinc [5]. Clarifying these postulations is hampered by the immense number of enzymes that use or are inhibited by zinc. Furthermore, the affinity of MTs for zinc probably differs depending on the stimulus by which MTs are induced. In an in vivo displacement assay of cadmium (whose affinity for MT is stronger than that of zinc), it was shown that oxidative stress-induced MT displaced zinc to cadmium, on the other hand, MT induced by fasting stress or by restraint stress did not [20]. This study did not make a distinction between different MT isoforms, although metal-binding capacities of isoforms can vary [21, $22]$, as can their gene-regulation [23, 24]. Conformational changes of MT under certain stimuli might also explain the observed influence on zinc affinity. It has been shown that the binding of ATP (which reflects the energy state of a cell) to MT elicited conformational changes and altered zinc binding in MT [25].

Zinc deficiency is a potential complication of Crohn's disease and may result from a variety of processes, including reduced dietary intake, impaired absorption, increased excretion, hypoalbuminemia, or an internal redistribution of zinc $[26,27]$. Although the consequences of this deficiency on the pathogenesis of the disease are not clear [28], it could be implicated through the involvement of zinc in immune function, redox signalling, and wound healing [2932]. Zinc is crucial for the normal development and function of cells mediating innate immunity, that is, neutrophils, macrophages, and natural killer cells [33]. Phagocytosis, intracellular killing, chemotaxis, and oxidative burst are all negatively affected by zinc deficiency. In Crohn's disease, a defective innate immune response is more and more accepted as a pathogenic mechanism [34]. Zinc also has antiinflammatory properties. An important target herein is nuclear factor (NF) $-\kappa \mathrm{B}$, a transcription factor that has a pivotal role in immune and inflammatory responses and as such also in IBD. Effects of zinc on NF- $\kappa$ B activity have been attributed to its influence on the expression of the zincfinger protein A20 that sequesters NF- $\kappa$ B in the cytoplasm and inhibits IL-1- and TNF- $\alpha$-induced activation of NF- $\kappa$ B [35]. In vitro, zinc enhances the upregulation of A-20, thus decreasing NF- $\kappa \mathrm{B}$ activation and leading to decreased gene expression and generation of TNF- $\alpha$, IL- $1 \beta$, and IL-8 [36]. Taking these findings into account, a lack of intracellular zinc ion bioavailability may hamper the inhibition of NF- $\kappa \mathrm{B}$, with subsequent maintenance of chronic inflammation.

The gene expression of IL-2, IL-12, and IFN- $\gamma$ (T helper type 1 or Th 1 cytokines) is zinc dependent, whereas T helper type 2 (Th2) cytokines in general are not affected by zinc deficiency [33]. As a consequence, an imbalance of Th1/Th2 cytokines appears in an experimental model of human zinc deficiency with a decrease of Th1 cytokines and a shift toward a Th2 phenotype [37]. This observation stands in contrast with the excessive Th1 cell response in the inflamed mucosa of Crohn's disease patients with active disease. However, in Crohn's disease patients with inactive disease, hyposecretion of IFN- $\gamma$ is reported $[38,39]$. Even though a relationship with zinc status has not been examined in these studies, zinc deficiency could be at the basis of this observation.

Studies where zinc was administered to rats or mice with chemically induced colitis showed a dose-dependent therapeutic effect [40-44]. Furthermore, zinc was shown to induce MT synthesis in ileal and colonic mucosa of control rats and to a lesser extent in that of colitic rats [45]. A placebo-controlled double-blind cross-over trial was conducted with seven Crohn's disease patients and seven ulcerative colitis patients that had inactive to moderately active disease and received oral zinc supplementation [46]. Although supplementation increased plasma zinc concentrations and slightly (but not significantly) increased mucosal MT concentration, there were no changes in histological inflammation or disease activity. However, it seems that zinc supplementation can resolve permeability alterations in patients with Crohn's disease in remission and as such reduce the risk of relapse in Crohn's disease [47]. This observation is supported by data that show a positive effect of exogenous zinc on intestinal repair in vitro [30] and on tightjunction permeability in experimental colitis [42]. Although the precise mechanism is not understood, it appears to be independent of MTs [48].

Next to their role in zinc homeostasis, MTs are reported to modulate the activation of NF- $\kappa \mathrm{B}$. However, published results vary concerning the relationship between MT expression level and NF- $\kappa \mathrm{B}$ activity. The modulatory effect might be based upon a direct interaction [49], regulation of zinc concentrations [50], or modulation of the redox balance through antioxidant functions [51]. Data supporting a positive regulatory role for MTs on NF- $\kappa \mathrm{B}$ activity are the zincinduced inhibition of this activity. Through sequestration 


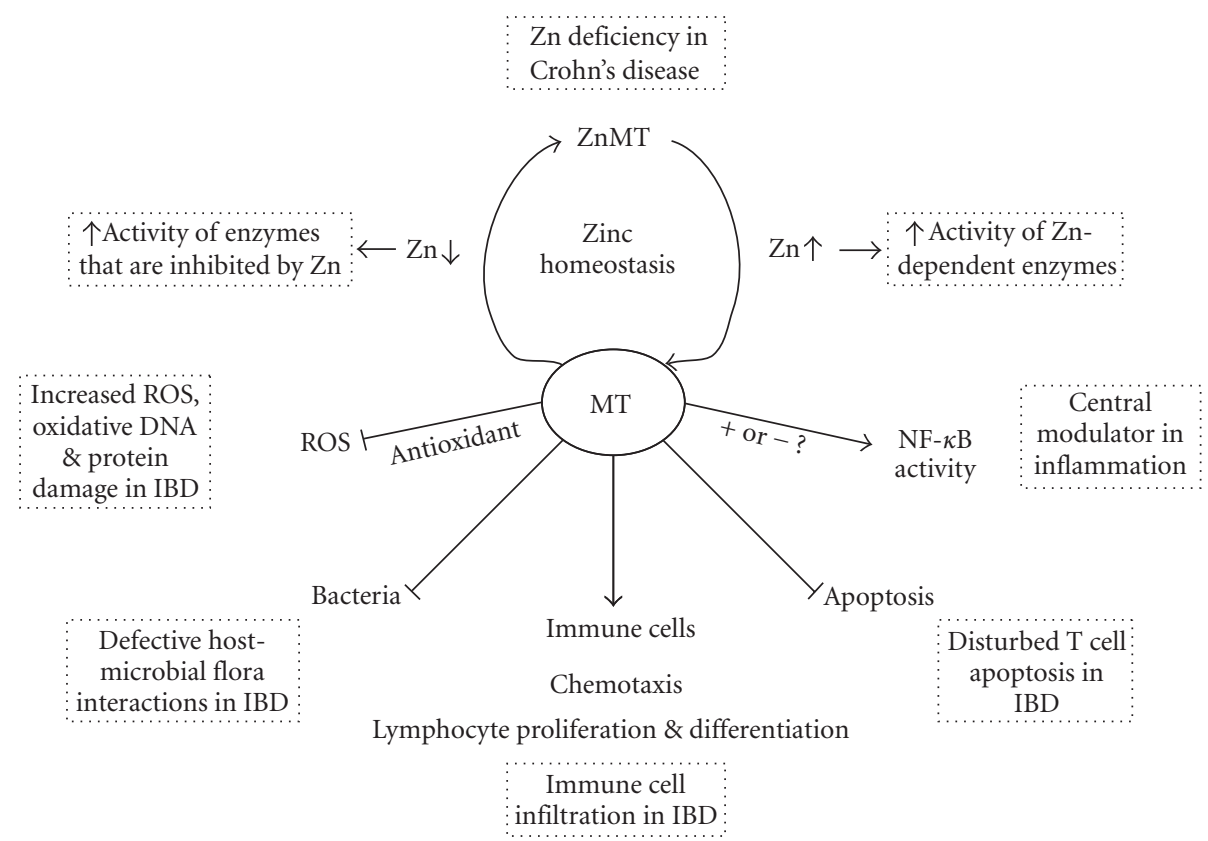

FIGURE 1: MT functions relevant in IBD. IBD is characterized by the presence of an increased level of ROS in the mucosal intestinal tissue as well as oxidative DNA and protein damage, defective host-microbe interactions, immune cell infiltration, and a disturbed T cell apoptosis. On all of these elements, MTs can have effects. In addition, MTs can have a dual role in enzyme activation through the release or sequestration of zinc. Finally, MTs are reported to regulate the activation of the transcription factor NF- $\kappa$ B, which has a key role in inflammatory responses.

of zinc, MTs can attenuate this zinc-induced inhibition and activate NF- $\kappa \mathrm{B}$ [50]. The requirement of MTs for the expression of macrophage colony stimulating factor, a chemokine downstream of NF- $\kappa \mathrm{B}$, is another illustration of this positive regulatory role [52]. On the other hand, data exist that MTs may function as a negative regulator of $N F-\kappa B$, showing that MTs inhibited the activation of NF- $\kappa$ B by TNF$\alpha[53,54]$ and that splenocytes from MTnull mice displayed elevated levels of NF- $\kappa$ B activity [55]. Although these reports seem contradictory, explanations for this discrepancy could be found in the distinct redox regulation of NF- $\kappa$ B activation between the cytoplasm and the nucleus [51], a balance which may be modulated by the antioxidant capacities of MTs. Another explanation might be found in differences in the cell types used. Although it seems obvious that a (negative or positive) correlation exists, MT effects can also be independent of NF- $\kappa$ B. For example, a protective effect of MTs on acute inflammatory lung injury was not mediated via NF- $\kappa \mathrm{B}$ dependent pathways [56]. Thus, to determine the exact role of MTs in the NF- $\kappa$ B pathway in IBD, NF$\kappa \mathrm{B}$ activity should be investigated in vivo in experimental models.

As just mentioned, the antioxidant capacities of MTs might influence the inflammatory response through modulating NF- $\kappa$ B activity, but a more obvious role for MTs as antioxidants is the sequestration of harmful oxygen and nitrogen intermediates which are generated during the inflammatory response. In order to kill bacteria and parasites, infiltrating neutrophils and macrophages produce free oxygen radicals (hydrogen peroxide, $\mathrm{NO}$, and superoxide anion) which are extremely cytotoxic to host cells $[57,58]$.
MTs can, together with other known molecules such as superoxide dismutase, vitamin $\mathrm{E}$, and ascorbate, provide a cytoprotection for host cells, preventing cellular damage and allowing survival and growth in an inflammatory environment [59]. The increased presence of ROS, an imbalance in antioxidant expression, and oxidative DNA and protein damage have been reported in IBD [60-63]. In Crohn's disease, oxidative damage as measured by lipid peroxidation correlated inversely with the concentration of MTs [61]. ROS can disrupt the epithelial barrier function by destabilizing tight junctions [64], thus increasing permeability, a phenomenon which is observed in patients with Crohn's disease [65]. Experiments in animal models of IBD have already confirmed the possibility to use antioxidants as therapeutic agents [66-69]. In IL-10 deficient mice, local mucosal administration of the antioxidant enzyme superoxide dismutase (SOD) by genetically modified Lactobacillus bacteria significantly reduced the severity of inflammation [70]. Mice overexpressing human SOD demonstrated attenuated inflammation when subjected to a mild form of dextran sodium sulphate- (DSS-) induced colitis and a remarkable survival benefit from severe DSS colitis [71].

In certain oxidative and inflammatory environments MTs have been shown to reduce apoptosis [72], and in cases where inflammation-dependent apoptosis is detrimental, induction of MTs might provide a benefit. Since Crohn's disease is characterized by defective T cell apoptosis, whereas $\mathrm{T}$ cells from ulcerative colitis patients show a strong activation induced apoptosis, the role of MTs might be different in these two diseases. MTs have also been accredited antimicrobial properties $[73,74]$, which might be another 
relevant feature given the defective interaction of the host with the mucosal flora in IBD. Macrophages isolated from MTnull mice showed a significantly lower bactericidal effect on Staphylococcus aureus than macrophages from control mice. Furthermore, LPS- and TNF- $\alpha$-stimulated MT-null macrophages produced less NO than those from control mice, which was due to reduced activity of inducible $\mathrm{NO}$ synthase [73]. One MT isoform that was isolated and purified from housefly larvae had direct antibacterial effects on Escherichia coli as assayed by the plate growth inhibition assay [74].

Under certain conditions such as cell proliferation, differentiation, and after cell injury, MTs are translocated from the cytosol to the nucleus. MT regulation during cell cycle progression has been demonstrated in normally cycling cells, with maximal nuclear accumulation within the $S$ and G2 phases. High cytoplasmic expression occurred during late G1 and G1/S transition, and basal amounts were found in the G0 phase $[75,76]$. Hepatocytes show a transient nuclear localization of MTs at the G1-to-S phase transition during the priming phase of liver cell regeneration after partial hepatectomy [77]. Two premises for the nuclear retention of MTs have been proposed. First, it might reflect the role of MTs as chaperones to provide zinc for crucial enzymes and transcription factors involved in cell division [78]. Otherwise, it has been proposed that it might protect DNA from oxidative damage [79].

Beside their intracellular functions, MTs could also be involved in inflammation and IBD through specific extracellular effects [80]. For example, MTs have been shown to directly and specifically mediate leukocyte chemotaxis [81]. Extracellular MTs can stimulate lymphocyte proliferation [82]. MT binds to the plasma membrane of both $\mathrm{T}$ and $\mathrm{B}$ lymphocytes, but, in the absence of a costimulatory agent, MT induces lymphoproliferation only in B cells. MT also enhances the capacity of naive B lymphocytes to differentiate into plasma cells [83]. On the other hand, MTs can suppress cytotoxic $\mathrm{T}$ cell function in vitro and a T-dependent humoral response in vivo [84-86].

\section{MT Expression in IBD}

Given their possible functions in IBD pathogenesis, the expression of MTs has been studied in patient samples by different research groups. These studies have yielded contradictory results (Table 1) and as such the role of MTs in IBD is not yet clarified. First of all, two studies reported an increase in MT expression in IBD $[87,88]$, while the rest demonstrated a downregulation. In most studies no differences were reported between Crohn's disease and ulcerative colitis, except in two studies (both using DNA microarrays) where opposite findings were found, that is, decreased MT expression in ulcerative colitis and normal expression in Crohn's disease [89] versus normal expression in ulcerative colitis and increased MT expression in Crohn's disease [88]. The influence of medication is also not clear yet, given that one study reports an influence of steroid therapy on MT expression [90] whereas a second study contests this [91]. A study describing downregulation of MTs in vitro in colon epithelial cells after stimulation with azathioprine did not discuss this effect in patients, although two azathioprinetreated patients were included in the study [88]. The results of this study should be interpreted cautiously, considering the small dataset used. Finally, the immunohistochemical studies do not agree whether MT expression is confined to the epithelium [92-94] or whether expression in the lamina propria occurs as well $[87,90,91]$. The study of MT protein expression in IBD is even complicated by the possible destructive influence of the oxidative environment on the immunodominant epitope of the protein. Therefore, it is not sure whether the absence of immunoreactivity equals absence of MT protein or whether it reflects a failure of the antibody to recognize the present protein.

The inconsistencies between the various studies could be explained by different sampling. MT expression could depend on the grade of local inflammation but also on the intestinal region, that is, ileum versus colon. Therefore, an ileal sample that has signs of mild inflammation and a piece of colonic tissue that suffers severe inflammation, both from a Crohn's disease patient, may possibly show different MT expression levels, although they will both be considered "Crohn's disease" samples. Therefore, careful sampling and precise classification of the samples could help in elucidating the exact MT expression pattern in IBD. Furthermore, patient characteristics such as age, medication, disease activity, zinc status, or even food intake before sampling could also influence MT levels and should therefore, if possible, be examined or at least mentioned in the study outline.

\section{MTs in Experimental Colitis Models}

The availability of MTnull mice (knockout for MT1 and MT2) and the use of recombinant MT have permitted the investigation of the involvement of MTs in animal models of inflammation. In the DSS model of colitis, MTs were not protective in two separate studies comparing MTnull mice with wild type mice $[44,94]$. One of these studies even found that, after DSS administration, MTnull mice had a significantly lower disease activity index than had wild type mice [44], suggesting that MTs are rather unfavorable in DSS colitis. This finding was, however, not confirmed on histology. In disagreement with this postulation is the observation that, in the same study, administration of zinc as an MT-inducer resulted in a lower disease activity index and less histological damage. Nevertheless, it could not be proven that this effect was MT-dependent since no increase in colonic MT-levels was found following zinc-treatment. The second study did not provide disease activity indices and found no differences in histological colon damage between MTnull mice, wild type mice, and transgenic mice overexpressing MT1 in the intestine [94]. This study found a fourfold increase in total colon MT concentration after seven days of DSS administration, different from other studies in experimental colitis that found no changes [44] or a decrease in MT content [45] in DSS mice or in dinitrobenzenesulphonic acid colitic rats, respectively. Apparently, the behaviour of MTs in experimental colitis models is as obscure as in human IBD. 
TABLE 1: MT expression in IBD patients. CD: Crohn's disease, UC: ulcerative colitis, IHC: immunohistochemistry, RIA: radio-immunoassay, Ag-hem: Silver-heme saturation assay, and qRT-PCR: quantitative reverse transcriptase-polymerase chain reaction.

\begin{tabular}{|c|c|c|c|}
\hline Study & Subjects & Methods & Results \\
\hline Clarkson et al. [90] & $\begin{array}{l}\text { Ileal resection specimens of } 13 \mathrm{CD} \\
\text { patients ( } 6 \text { had received steroid } \\
\text { therapy; } 5 \text { had not), } 2 \text { UC patients, } \\
\text { and } 3 \text { controls }\end{array}$ & $\begin{array}{l}\text { IHC on resection } \\
\text { specimens }\end{array}$ & $\begin{array}{l}\text { Less MT immunoreactivity in patients with } \\
\text { IBD than controls; patients on steroid therapy } \\
\text { had more immunoreactivity; } \\
\text { immunoreactivity in enterocytes and lamina } \\
\text { propria }\end{array}$ \\
\hline Elmes et al. [91] & $\begin{array}{l}\text { Ileal resection specimens of } 17 \mathrm{CD} \\
\text { patients ( } 11 \text { had received steroid } \\
\text { therapy; } 6 \text { had not), and } 5 \text { controls }\end{array}$ & $\begin{array}{l}\text { IHC on resection } \\
\text { specimens }\end{array}$ & $\begin{array}{l}\text { Decreased intestinal MT in IBD patients; no } \\
\text { significant difference when patients had } \\
\text { received steroid therapy; immunoreactivity in } \\
\text { enterocytes and basement membrane region }\end{array}$ \\
\hline Mulder et al. [95] & $\begin{array}{l}19 \text { ileum and } 16 \text { colon specimens } \\
\text { from } 29 \text { CD patients; } 12 \text { colon } \\
\text { specimens and } 1 \text { ileum specimen } \\
\text { from } 12 \text { UC patients; colon } \\
\text { specimens from } 18 \text { control patients }\end{array}$ & $\begin{array}{l}\text { RIA on homogenized } \\
\text { mucosa (dissected } \\
\text { from resection } \\
\text { specimens) }\end{array}$ & $\begin{array}{l}\text { MT content was decreased in noninflamed IBD } \\
\text { mucosa compared with control mucosa; } \\
\text { further decrease, was found in inflamed } \\
\text { mucosa; no differences between UC and CD; } \\
\text { no significant effect of medication or tissue } \\
\text { localization }\end{array}$ \\
\hline Sturniolo et al. [96] & $\begin{array}{l}\text { Colonic biopsies of } 24 \text { UC patients } \\
\text { and } 10 \text { controls }\end{array}$ & Ag-hem on biopsies & $\begin{array}{l}\text { Reduced MT concentrations in patients with } \\
\text { active disease as compared with controls and } \\
\text { patients in remission; reduced MT } \\
\text { concentrations in inflamed versus noninflamed } \\
\text { mucosa taken from the same patient }\end{array}$ \\
\hline Bruwer et al. [87] & $\begin{array}{l}22 \text { CD patients, } 48 \text { UC patients, } 10 \\
\text { controls }\end{array}$ & $\begin{array}{l}\text { IHC on resection } \\
\text { specimens }\end{array}$ & $\begin{array}{l}\text { MT overexpression in the fibroblasts of all } \\
\text { ulcerative and/or fissural lesions in UC and } \\
\text { CD; MT overexpression in intestinal epithelial } \\
\text { cells of } 40 \% \text { of UC and CD lesions correlated } \\
\text { significantly with the grade of inflammation }\end{array}$ \\
\hline
\end{tabular}

Colonic resection specimens with moderately severe histological Lawrance et al. [89] inflammation from 12 UC and 6 CD patients (with moderately DNA microarray Decrease of MT1H and MT1G mRNA severe clinical disease) and from 6 controls

\begin{tabular}{|c|c|c|c|}
\hline Ioachim et al. [92] & $\begin{array}{l}\text { Ileum, colon or rectum resection } \\
\text { specimens from } 10 \mathrm{CD} \text { patients, } 41 \\
\text { UC patients, } 5 \text { controls }\end{array}$ & IHC & $\begin{array}{l}\text { Decreased MT expression in UC and CD } \\
\text { compared with normal mucosa; no difference } \\
\text { in MT expression between UC and CD; in UC, } \\
\text { a gradually decreased expression from } \\
\text { remission, to resolving and to active phase was } \\
\text { observed; only epithelial MT expression }\end{array}$ \\
\hline Kruidenier et al. [93] & $\begin{array}{l}\text { Resection specimens from } 19 \mathrm{CD} \\
\text { patients, } 15 \text { UC patients, } 18 \text { controls }\end{array}$ & $\begin{array}{l}\text { RIA on tissue } \\
\text { homogenates and IHC } \\
\text { on resection specimens }\end{array}$ & $\begin{array}{l}\text { RIA: Lower tissue MT content in inflamed CD } \\
\text { and UC mucosa compared with noninflamed } \\
\text { and control mucosa; IHC: decreased } \\
\text { MT-positive epithelial cell numbers at } \\
\text { inflamed sites in CD and UC patients; no } \\
\text { detection of MT in lamina propria }\end{array}$ \\
\hline Dooley et al. [88] & $\begin{array}{l}2 \text { sets of colon samples: (a) control } \\
\text { ( } 1 \text { uninvolved colon from CD } \\
\text { patient), } 1 \text { CD patient, and } 1 \mathrm{UC} \\
\text { patient; (b) control, } 1 \\
\text { azathioprine-treated CD patient, } \\
\text { and } 1 \text { azathioprine-treated UC } \\
\text { patient; drug-treated CaCo-2 cells }\end{array}$ & $\begin{array}{l}\text { microarray and } \\
\text { qRT-PCR with } \\
\text { consensus primer } \\
\text { sequences for multiple } \\
\text { metallothionein genes. }\end{array}$ & $\begin{array}{l}\text { Microarray: upregulation of MT1F, MT1G, } \\
\text { MT1H in CD in tissue set (a); downregulation } \\
\text { of MT1F, MT1H, MT1L in } \\
\text { azathioprine-treated CaCo-2 cells; confirmed } \\
\text { by qRT-PCR }\end{array}$ \\
\hline
\end{tabular}

\section{Protective Functions of MTs in Other Animal Models of Inflammation}

The role of MTs in models of other inflammatory conditions seems clearer and in most cases is a favorable one. In an animal model for multiple sclerosis, a chronic inflammatory and demyelinating disease of the central nervous system in which oxidative stress plays a pathogenic role, MTs were demonstrated to be protective [97]. MTnull mice were more susceptible to Helicobacter pylori-induced gastritis and 
showed more severe inflammation of the stomach than wild type mice [98]. This correlates with the reported antibacterial activity that was associated with MT function. This activity might be mediated directly by MTs themselves [74] or indirectly through nitric oxide production [73]. Endogenous MT protected against acute lung injury induced by LPS, especially against pulmonary oedema [56]. In the collageninduced arthritis model, repeated administration of MT1 and 2 during the course of disease dramatically reduced the incidence and severity of the disease [99]. MTs suppressed the disease through the generation of IL-10- and transforming growth factor (TGF)- $\beta$-producing type 1 regulatory $\mathrm{T}$ like cells [100]. In all of these models, MTs seem to be protective against local inflammation. In the TNF-induced lethal shock model (a model for systemic inflammatory response syndrome), however, MTs seem to sensitize [101]. An explanation for this finding was not found, although it is contradictory to the reported resistance that MTs confer to the cytotoxic effects of TNF in vitro [102] and to the protective effects of MTs in another model of systemic inflammatory response syndrome (LPS-induced lethal shock in sensitized mice) [103]. The antiinflammatory effects of MTs on the LPS-related organ damages could be mediated, at least in part, via the inhibition of the protein expression of proinflammatory cytokines (IL- $1 \beta$, IL-6) and chemokines (granulocyte/macrophage colony-stimulating factor (GMCSF), macrophage inflammatory protein (MIP)- $1 \alpha$, MIP2 , macrophage chemoattractant protein (MCP)-1, and keratinocyte chemoattractant (KC)) [104].

\section{Conclusion}

Although several functional associations of MTs can confer a role for this family of proteins in the pathogenesis of IBD, the results of human and experimental colitis studies are not decisive. However, it is clear that a deviant MT expression exists in this disease, and as such it is important to meticulously clarify these aberrations in Crohn's disease and in ulcerative colitis. Furthermore, investigating whether the regulation of MTs in these diseases is dependent or independent on inflammation will add knowledge on their involvement in IBD.

\section{Acknowledgment}

The authors are very grateful to Dr. Michael A. Lynes for helpful discussion.

\section{References}

[1] B. L. Vallee, "Introduction to metallothionein," Methods in Enzymology, vol. 205, pp. 3-7, 1991.

[2] Y. Kojima, C. Berger, B. L. Vallee, and J. H. R. Kagi, "Amino-acid sequence of equine renal metallothionein-1B," Proceedings of the National Academy of Sciences of the United States of America, vol. 73, no. 10, pp. 3413-3417, 1976.

[3] D. Laukens, A. Waeytens, P. De Bleser, C. Cuvelier, and M. De Vos, "Metallothionein expression under normal and pathological conditions: mechanisms of gene regulation based on in silico promoter analysis," Critical Reviews in Eukaryotic Gene Expression, vol. 19, no. 4, pp. 301-317, 2009.

[4] M. Karin, R. L. Eddy, W. M. Henry, L. L. Haley, M. G. Byers, and T. B. Shows, "Human metallothionein genes are clustered on chromosome 16," Proceedings of the National Academy of Sciences of the United States of America, vol. 81, no. 17, pp. 5494-5498, 1984.

[5] P. Coyle, J. C. Philcox, L. C. Carey, and A. M. Rofe, "Metallothionein: the multipurpose protein," Cellular and Molecular Life Sciences, vol. 59, no. 4, pp. 627-647, 2002.

[6] S. Tsuji, H. Kobayashi, Y. Uchida, Y. Ihara, and T. Miyatake, "Molecular cloning of human growth inhibitory factor cDNA and its down-regulation in Alzheimer's disease," The EMBO Journal, vol. 11, no. 13, pp. 4843-4850, 1992.

[7] J. G. Hoey, S. H. Garrett, M. A. Sens, J. H. Todd, and D. A. Sens, "Expression of MT-3 mRNA in human kidney, proximal tubule cell cultures, and renal cell carcinoma," Toxicology Letters, vol. 92, no. 2, pp. 149-160, 1997.

[8] P. Moffatt and C. Séguin, "Expression of the gene encoding metallothionein-3 in organs of the reproductive system," DNA and Cell Biology, vol. 17, no. 6, pp. 501-510, 1998.

[9] C. J. Quaife, S. D. Findley, J. C. Erickson, et al., "Induction of a new metallothionein isoform (MT-IV) occurs during differentiation of stratified squamous epithelia," Biochemistry, vol. 33, no. 23, pp. 7250-7259, 1994.

[10] A. T. Miles, G. M. Hawksworth, J. H. Beattie, and V. Rodilla, "Induction, regulation, degradation, and biological significance of mammalian metallothioneins," Critical Reviews in Biochemistry and Molecular Biology, vol. 35, no. 1, pp. 35-70, 2000.

[11] S. K. De, M. T. McMaster, and G. K. Andrews, "Endotoxin induction of murine metallothionein gene expression," The Journal of Biological Chemistry, vol. 265, no. 25, pp. 1526715274, 1990.

[12] K. Arizono, S.-I. Kagawa, H. Hamada, and T. Ariyoshi, "Nitric oxide mediated metallothionein induction by lipopolysaccharide," Research Communications in Molecular Pathology and Pharmacology, vol. 90, no. 1, pp. 49-58, 1995.

[13] N. Itoh, K. Kasutani, N. Muto, N. Otaki, M. Kimura, and K. Tanaka, "Blocking effect of anti-mouse interleukin-6 monoclonal antibody and glucocorticoid receptor antagonist, RU38486, on metallothionein-inducing activity of serum from lipopolysaccharide-treated mice," Toxicology, vol. 112, no. 1, pp. 29-36, 1996.

[14] R. J. Cousins and A. S. Leinart, "Tissue-specific regulation of zinc metabolism and metallothionein genes by interleukin 1," The FASEB Journal, vol. 2, no. 13, pp. 2884-2890, 1988.

[15] J. J. Schroeder and R. J. Cousins, "Interleukin 6 regulates metallothionein gene expression and zinc metabolism in hepatocyte monolayer cultures," Proceedings of the National Academy of Sciences of the United States of America, vol. 87, no. 8, pp. 3137-3141, 1990.

[16] M. Sato, M. Sasaki, and H. Hojo, "Differential induction of metallothionein synthesis by interleukin-6 and tumor necrosis factor- $\alpha$ in rat tissues," International Journal of Immunopharmacology, vol. 16, no. 2, pp. 187-195, 1994.

[17] Y. Ren and A. Smith, "Mechanism of metallothionein gene regulation by heme-hemopexin-roles of protein kinase C, reactive oxygen species, and cis-acting elements," The Journal of Biological Chemistry, vol. 270, no. 41, pp. 23988-23995, 1995.

[18] G. K. Andrews, "Regulation of metallothionein gene expression by oxidative stress and metal ions," Biochemical Pharmacology, vol. 59, no. 1, pp. 95-104, 2000. 
[19] C. Haton, A. Francois, M. Vandamme, J. Wysocki, N. M. Griffiths, and M. Benderitter, "Imbalance of the antioxidant network of mouse small intestinal mucosa after radiation exposure," Radiation Research, vol. 167, no. 4, pp. 445-453, 2007.

[20] M. Kondoh, N. Imada, K. Kamada, et al., "Property of metallothionein as a $\mathrm{Zn}$ pool differs depending on the induced condition of metallothionein," Toxicology Letters, vol. 142, no. 1-2, pp. 11-18, 2003.

[21] P. Palumaa, E. Eriste, O. Njunkova, L. Pokras, H. Jornvall, and R. Sillard, "Brain-specific metallothionein-3 has higher metal-binding capacity than ubiquitous metallothioneins and binds metals noncooperatively," Biochemistry, vol. 41, no. 19, pp. 6158-6163, 2002.

[22] L. Tio, L. Villarreal, S. Atrian, and M. Capdevila, "Functional differentiation in the mammalian metallothionein gene family-metal binding features of mouse MT4 and comparison with its paralog MT1," The Journal of Biological Chemistry, vol. 279, no. 23, pp. 24403-24413, 2004.

[23] C. J. Schmidt and D. H. Hamer, "Cell specificity and an effect of ras on human metallothionein gene expression," Proceedings of the National Academy of Sciences of the United States of America, vol. 83, no. 10, pp. 3346-3350, 1986.

[24] N. Jahroudi, R. Foster, J. Price-Haughey, G. Beitel, and L. Gedamu, "Cell-type specific and differential regulation of the human metallothionein genes. Correlation with DNA methylation and chromatin structure," The Journal of Biological Chemistry, vol. 265, no. 11, pp. 6506-6511, 1990.

[25] L.-J. Jiang, W. Maret, and B. L. Vallee, "The ATPmetallothionein complex," Proceedings of the National Academy of Sciences of the United States of America, vol. 95, no. 16, pp. 9146-9149, 1998.

[26] T. Matsui, "Zinc deficiency in Crohn's disease," Journal of Gastroenterology, vol. 33, no. 6, pp. 924-925, 1998.

[27] J. Goh and C. A. O'Morain, "Review article: nutrition and adult inflammatory bowel disease," Alimentary Pharmacology \& Therapeutics, vol. 17, no. 3, pp. 307-320, 2003.

[28] C. Ainley, J. Cason, B. M. Slavin, R. A. Wolstencroft, and R. P. H. Thompson, "The influence of zinc status and malnutrition on immunological function in Crohn's disease," Gastroenterology, vol. 100, no. 6, pp. 1616-1625, 1991.

[29] A. H. Shankar and A. S. Prasad, "Zinc and immune function: the biological basis of altered resistance to infection," American Journal of Clinical Nutrition, vol. 68, no. 2, pp. 447S463S, 1998.

[30] E. Cario, S. Jung, J. D. Harder, et al., "Effects of exogenous zinc supplementation on intestinal epithelial repair in vitro," European Journal of Clinical Investigation, vol. 30, no. 5, pp. 419-428, 2000.

[31] W. Maret, "Zinc coordination environments in proteins as redox sensors and signal transducers," Antioxidants \& Redox Signaling, vol. 8, no. 9-10, pp. 1419-1441, 2006.

[32] S. Vasto, E. Mocchegiani, M. Malavolta, et al., "Zinc and inflammatory/immune response in aging," Annals of the New York Academy of Sciences, vol. 1100, pp. 111-122, 2007.

[33] A. S. Prasad, "Clinical, immunological, anti-inflammatory and antioxidant roles of zinc," Experimental Gerontology, vol. 43, no. 5, pp. 370-377, 2008.

[34] M. Comalada and M. P. Peppelenbosch, "Impaired innate immunity in Crohn's disease," Trends in Molecular Medicine, vol. 12, no. 9, pp. 397-399, 2006.

[35] M. Jaattela, H. Mouritzen, F. Elling, and L. Bastholm, "A20 zinc finger protein inhibits TNF and IL-1 signaling," The Journal of Immunology, vol. 156, no. 3, pp. 1166-1173, 1996.
[36] A. S. Prasad, B. Bao, F. W. J. Beck, O. Kucuk, and F. H. Sarkar, "Antioxidant effect of zinc in humans," Free Radical Biology and Medicine, vol. 37, no. 8, pp. 1182-1190, 2004.

[37] A. S. Prasad, "Effects of zinc deficiency on Th1 and Th2 cytokine shifts," Journal of Infectious Diseases, vol. 182, no. 3, pp. S62-S68, 2000.

[38] D. Raddatz, M. Bockemuhl, and G. Ramadori, "Quantitative measurement of cytokine mRNA in inflammatory bowel disease: relation to clinical and endoscopic activity and outcome," European Journal of Gastroenterology \& Hepatology, vol. 17, no. 5, pp. 547-557, 2005.

[39] J. Sventoraityte, A. Zvirbliene, G. Kiudelis, et al., "Immune system alterations in patients with inflammatory bowel disease during remission," Medicina, vol. 44, no. 1, pp. 2733, 2008.

[40] B.-W. Chen, H.-H. Wang, J.-X. Liu, and X.-G. Liu, "Zinc sulphate solution enema decreases inflammation in experimental colitis in rats," Journal of Gastroenterology and Hepatology, vol. 14, no. 11, pp. 1088-1092, 1999.

[41] H. H. Luk, J. K. S. Ko, H. S. Fung, and C. H. Cho, "Delineation of the protective action of zinc sulfate on ulcerative colitis in rats," European Journal of Pharmacology, vol. 443, no. 1-3, pp. 197-204, 2002.

[42] G. C. Sturniolo, W. Fries, E. Mazzon, V. Di Leo, M. Barollo, and R. D'Inca, "Effect of zinc supplementation on intestinal permeability in experimental colitis," Journal of Laboratory and Clinical Medicine, vol. 139, no. 5, pp. 311-315, 2002.

[43] T. Ohkawara, H. Takeda, K. Kato, et al., "Polaprezinc (N(3-aminopropionyl)-L-histidinato zinc) ameliorates dextran sulfate sodium-induced colitis in mice," Scandinavian Journal of Gastroenterology, vol. 40, no. 11, pp. 1321-1327, 2005.

[44] C. D. Tran, J. M. Ball, S. Sundar, P. Coyle, and G. S. Howarth, "The role of zinc and metallothionein in the dextran sulfate sodium-induced colitis mouse model," Digestive Diseases and Sciences, vol. 52, no. 9, pp. 2113-2121, 2007.

[45] V. Di Leo, R. D’Inca, M. Barollo, et al., "Effect of zinc supplementation on trace elements and intestinal metallothionein concentrations in experimental colitis in the rat," Digestive and Liver Disease, vol. 33, no. 2, pp. 135-139, 2001.

[46] T. P. J. Mulder, A. van der Sluys Veer, H. W. Verspaget, et al., "Effect of oral zinc supplementation on metallothionein and superoxide dismutase concentrations in patients with inflammatory bowel disease," Journal of Gastroenterology and Hepatology, vol. 9, no. 5, pp. 472-477, 1994.

[47] G. C. Sturniolo, V. Di Leo, A. Ferronato, A. D'Odorico, and R. D'Incà, "Zinc supplementation tightens "Leaky Gut" in Crohn's disease," Inflammatory Bowel Diseases, vol. 7, no. 2, pp. 94-98, 2001.

[48] J. C. Lambert, Z. Zhou, L. Wang, Z. Song, C. J. McClain, and Y. J. Kang, "Preservation of intestinal structural integrity by zinc is independent of metallothionein in alcohol-intoxicated mice," American Journal of Pathology, vol. 164, no. 6, pp. 1959-1966, 2004.

[49] A. B. Abdel-Mageed and K. C. Agrawal, "Activation of nuclear factor $\kappa \mathrm{B}$ : potential role in metallothionein-mediated mitogenic response," Cancer Research, vol. 58, no. 11, pp. 2335-2338, 1998.

[50] C. H. Kim, J. H. Kim, J. Lee, and Y. S. Ahn, "Zinc-induced NF- $\kappa \mathrm{B}$ inhibition can be modulated by changes in the intracellular metallothionein level," Toxicology and Applied Pharmacology, vol. 190, no. 2, pp. 189-196, 2003.

[51] Y. Kabe, K. Ando, S. Hirao, M. Yoshida, and H. Handa, "Redox regulation of NF- $\kappa$ B activation: distinct redox regulation between the cytoplasm and the nucleus," Antioxidants \& Redox Signaling, vol. 7, no. 3-4, pp. 395-403, 2005. 
[52] M. Kanekiyo, N. Itoh, A. Kawasaki, K. Matsuda, T. Nakanishi, and K. Tanaka, "Metallothionein is required for zinc-induced expression of the macrophage colony stimulating factor gene," Journal of Cellular Biochemistry, vol. 86, no. 1, pp. 145153, 2002.

[53] A. Sakurai, S. Hara, N. Okano, Y. Kondo, J.-I. Inoue, and N. Imura, "Regulatory role of metallothionein in NF- $\kappa \mathrm{B}$ activation," FEBS Letters, vol. 455, no. 1-2, pp. 55-58, 1999.

[54] M. Kanekiyo, N. Itoh, A. Kawasaki, et al., "Metallothionein modulates lipopolysaccharide-stimulated tumour necrosis factor expression in mouse peritoneal macrophages," Biochemical Journal, vol. 361, no. 2, pp. 363-369, 2002.

[55] K. C. Crowthers, V. Kline, C. Giardina, and M. A. Lynes, "Augmented humoral immune function in metallothioneinnull mice," Toxicology and Applied Pharmacology, vol. 166, no. 3, pp. 161-172, 2000.

[56] H. Takano, K. Inoue, R. Yanagisawa, et al., "Protective role of metallothionein in acute lung injury induced by bacterial endotoxin," Thorax, vol. 59, no. 12, pp. 1057-1062, 2004.

[57] T. Yamada and M. B. Grisham, "Role of neutrophil-derived oxidants in the pathogenesis of intestinal inflammation," Klinische Wochenschrift, vol. 69, no. 21-23, pp. 988-994, 1991.

[58] Y. Naito, T. Takagi, and T. Yoshikawa, "Molecular fingerprints of neutrophil-dependent oxidative stress in inflammatory bowel disease," Journal of Gastroenterology, vol. 42, no. 10, pp. 787-798, 2007.

[59] P. Irato, G. Santovito, E. Piccinni, and V. Albergoni, "Oxidative burst and metallothionein as a scavenger in macrophages," Immunology and Cell Biology, vol. 79, no. 3, pp. 251-254, 2001.

[60] I. I. Singer, D. W. Kawka, S. Scott, et al., "Expression of inducible nitric oxide synthase and nitrotyrosine in colonic epithelium in inflammatory bowel disease," Gastroenterology, vol. 111, no. 4, pp. 871-885, 1996.

[61] L. Kruidenier, I. Kuiper, C. B. Lamers, and H. W. Verspaget, "Intestinal oxidative damage in inflammatory bowel disease: semi-quantification, localization, and association with mucosal antioxidants," Journal of Pathology, vol. 201, no. 1, pp. 28-36, 2003.

[62] A. Rezaie, F. Ghorbani, A. Eshghtork, et al., "Alterations in salivary antioxidants, nitric oxide, and transforming growth factor- $\beta 1$ in relation to disease activity in Crohn's disease patients," Annals of the New York Academy of Sciences, vol. 1091, pp. 110-122, 2006.

[63] Y. Dincer, Y. Erzin, S. Himmetoglu, K. N. Gunes, K. Bal, and T. Akcay, "Oxidative DNA damage and antioxidant activity in patients with inflammatory bowel disease," Digestive Diseases and Sciences, vol. 52, no. 7, pp. 1636-1641, 2007.

[64] R. Rao, "Oxidative stress-induced disruption of epithelial and endothelial tight junctions," Frontiers in Bioscience, vol. 13, pp. 7210-7226, 2008.

[65] D. Hollander, C. M. Vadheim, E. Brettholz, G. M. Petersen, T. Delahunty, and J. I. Rotter, "Increased intestinal permeability in patients with Crohn's disease and their relatives: a possible etiologic factor," Annals of Internal Medicine, vol. 105, no. 6, pp. 883-885, 1986.

[66] A. Keshavarzian, G. Morgan, S. Sedghi, J. H. Gordon, and M. Doria, "Role of reactive oxygen metabolites in experimental colitis," Gut, vol. 31, no. 7, pp. 786-790, 1990.

[67] J. Segui, M. Gironella, M. Sans, et al., "Superoxide dismutase ameliorates TNBS-induced colitis by reducing oxidative stress, adhesion molecule expression, and leukocyte recruitment into the inflamed intestine," Journal of Leukocyte Biology, vol. 76, no. 3, pp. 537-544, 2004.
[68] J. Segui, F. Gil, M. Gironella, et al., "Down-regulation of endothelial adhesion molecules and leukocyte adhesion by treatment with superoxide dismutase is beneficial in chronic immune experimental colitis," Inflammatory Bowel Diseases, vol. 11, no. 10, pp. 872-882, 2005.

[69] V. Vasina, M. Broccoli, M. G. Ursino, et al., "Effects of the non-peptidyl low molecular weight radical scavenger IAC in DNBS-induced colitis in rats," European Journal of Pharmacology, vol. 614, no. 1-3, pp. 137-145, 2009.

[70] I. M. Carroll, J. M. Andrus, J. M. Bruno-Barcena, T. R. Klaenhammer, H. M. Hassan, and D. S. Threadgill, "Antiinflammatory properties of Lactobacillus gasseri expressing manganese superoxide dismutase using the interleukin 10deficient mouse model of colitis," American Journal of Physiology, vol. 293, no. 4, pp. G729-G738, 2007.

[71] L. Kruidenier, M. E. van Meeteren, I. Kuiper, et al., "Attenuated mild colonic inflammation and improved survival from severe DSS-colitis of transgenic Cu/Zn-SOD mice," Free Radical Biology and Medicine, vol. 34, no. 6, pp. 753-765, 2003.

[72] M. Penkowa and J. Hidalgo, "Metallothionein treatment reduces proinflammatory cytokines IL- 6 and TNF- $\alpha$ and apoptotic cell death during experimental autoimmune encephalomyelitis (EAE)," Experimental Neurology, vol. 170, no. 1, pp. 1-14, 2001.

[73] N. Itoh, H. Shibayama, M. Kanekiyo, et al., "Reduced bactericidal activity and nitric oxide production in metallothioneindeficient macrophages in response to lipopolysaccharide stimulation," Toxicology, vol. 216, no. 2-3, pp. 188-196, 2005.

[74] H. Y. Jin, Q. Hui, J. Y. Jun, et al., "Preliminary studies on the zinc-induced metallothionein protein with antibacterial activity in housefly larvae, Musca domestica," Acta Biologica Hungarica, vol. 56, no. 3-4, pp. 283-295, 2005.

[75] K. Tsujikawa, T. Imai, M. Kakutani, et al., "Localization of metallothionein in nuclei of growing primary cultured adult rat hepatocytes," FEBS Letters, vol. 283, no. 2, pp. 239-242, 1991.

[76] W. W. Nagel and B. L. Vallee, "Cell cycle regulation of metallothionein in human colonic cancer cells," Proceedings of the National Academy of Sciences of the United States of America, vol. 92, no. 2, pp. 579-583, 1995.

[77] M. G. Cherian and Y. J. Kang, "Metallothionein and liver cell regeneration," Experimental Biology and Medicine, vol. 231, no. 2, pp. 138-144, 2006.

[78] C. Schmidt and D. Beyersmann, "Transient peaks in zinc and metallothionein levels during differentiation of 3T3L1 cells," Archives of Biochemistry and Biophysics, vol. 364, no. 1, pp. 91-98, 1999.

[79] M. Levadoux-Martin, J. E. Hesketh, J. H. Beattie, and H. M. Wallace, "Influence of metallothionein-1 localization on its function," Biochemical Journal, vol. 355, no. 2, pp. 473-479, 2001.

[80] M. A. Lynes, K. Zaffuto, D. W. Unfricht, G. Marusov, J. S. Samson, and X. Yin, "The physiological roles of extracellular metallothionein," Experimental Biology and Medicine, vol. 231, no. 9, pp. 1548-1554, 2006.

[81] X. Yin, D. A. Knecht, and M. A. Lynes, "Metallothionein mediates leukocyte chemotaxis," BMC Immunology, vol. 6, article 21, 2005.

[82] M. A. Lynes, J. S. Garvey, and D. A. Lawrence, "Extracellular metallothionein effects on lymphocyte activities," Molecular Immunology, vol. 27, no. 3, pp. 211-219, 1990.

[83] L. A. Borghesi, J. Youn, E. A. Olson, and M. A. Lynes, "Interactions of metallothionein with murine lymphocytes: 
plasma membrane binding and proliferation," Toxicology, vol. 108, no. 1-2, pp. 129-140, 1996.

[84] M. A. Lynes, L. A. Borghesi, J. Youn, and E. A. Olson, "Immunomodulatory activities of extracellular metallothionein I. Metallothionein effects on antibody production," Toxicology, vol. 85, no. 2-3, pp. 161-177, 1993.

[85] J. Youn and M. A. Lynes, "Metallothionein-induced suppression of cytotoxic T lymphocyte function: an important immunoregulatory control," Toxicological Sciences, vol. 52, no. 2, pp. 199-208, 1999.

[86] E. Canpolat and M. A. Lynes, "In vivo manipulation of endogenous metallothionein with a monoclonal antibody enhances T-dependent humoral immune response," Toxicological Sciences, vol. 62, no. 1, pp. 61-70, 2001.

[87] M. Bruwer, K. W. Schmid, K. A. Metz, C. F. Krieglstein, N. Senninger, and G. Schurmann, "Increased expression of metallothionein in inflammatory bowel disease," Inflammation Research, vol. 50, no. 6, pp. 289-293, 2001.

[88] T. P. Dooley, E. V. Curto, S. P. Reddy, et al., "Regulation of gene expression in inflammatory bowel disease and correlation with IBD drugs: screening by DNA microarrays," Inflammatory Bowel Diseases, vol. 10, no. 1, pp. 1-14, 2004.

[89] I. C. Lawrance, C. Fiocchi, and S. Chakravarti, "Ulcerative colitis and Crohn's disease: distinctive gene expression profiles and novel susceptibility candidate genes," Human Molecular Genetics, vol. 10, no. 5, pp. 445-456, 2001.

[90] J. P. Clarkson, M. E. Elmes, B. Jasani, and M. Webb, "Histological demonstration of immunoreactive zinc metallothionein in liver and ileum of rat and man," Histochemical Journal, vol. 17, no. 3, pp. 343-352, 1985.

[91] M. E. Elmes, J. P. Clarkson, and B. Jasani, "Histological demonstration of immunoreactive metallothionein in rat and human tissues," Experientia Supplementum, vol. 52, pp. 533-537, 1987.

[92] E. Ioachim, M. Michael, C. Katsanos, A. Demou, and E. V. Tsianos, "The immunohistochemical expression of metallothionein in inflammatory bowel disease. Correlation with HLA-DR antigen expression, lymphocyte subpopulations and proliferation-associated indices," Histology and Histopathology, vol. 18, no. 1, pp. 75-82, 2003.

[93] L. Kruidenier, I. Kuiper, W. van Duijn, et al., "Imbalanced secondary mucosal antioxidant response in inflammatory bowel disease," Journal of Pathology, vol. 201, no. 1, pp. 1727, 2003.

[94] H. S. Oz, T. Chen, W. J. S. de Villiers, and C. J. McClain, "Metallothionein overexpression does not protect against inflammatory bowel disease in a murine colitis model," Medical Science Monitor, vol. 11, no. 3, pp. BR69-BR73, 2005.

[95] T. P. J. Mulder, H. W. Verspaget, A. R. Janssenss, P. A. F. de Bruin, A. S. Pena, and C. B. H. W. Lamers, "Decrease in two intestinal copper/zinc containing proteins with antioxidant function in inflammatory bowel disease," Gut, vol. 32, no. 10, pp. 1146-1150, 1991.

[96] G. C. Sturniolo, C. Mestriner, P. E. Lecis, et al., "Altered plasma and mucosal concentrations of trace elements and antioxidants in active ulcerative colitis," Scandinavian Journal of Gastroenterology, vol. 33, no. 6, pp. 644-649, 1998.

[97] M. Penkowa, C. Espejo, E. M. Martinez-Caceres, C. B. Poulsen, X. Montalban, and J. Hidalgo, "Altered inflammatory response and increased neurodegeneration in metallothionein I+II deficient mice during experimental autoimmune encephalomyelitis," Journal of Neuroimmunology, vol. 119, no. 2, pp. 248-260, 2001.
[98] C. D. Tran, H. Huynh, M. van den Berg, et al., "Helicobacterinduced gastritis in mice not expressing metallothionein-I and II," Helicobacter, vol. 8, no. 5, pp. 533-541, 2003.

[99] J. Youn, S.-H. Hwang, Z.-Y. Ryoo, et al., "Metallothionein suppresses collagen-induced arthritis via induction of TGF$\beta$ and down-regulation of proinflammatory mediators," Clinical and Experimental Immunology, vol. 129, no. 2, pp. 232-239, 2002.

[100] S. Huh, K. Lee, H.-S. Yun, D.-J. Paik, J. M. Kim, and J. Youn, "Functions of metallothionein generating interleukin10 -producing regulatory $\mathrm{Cd} 4^{+} \mathrm{T}$ cells potentiate suppression of collagen-induced arthritis," Journal of Microbiology and Biotechnology, vol. 17, no. 2, pp. 348-358, 2007.

[101] W. Waelput, D. Broekaert, J. Vandekerckhove, P. Brouckaert, J. Tavernier, and C. Libert, "A mediator role for metallothionein in tumor necrosis factor-induced lethal shock," Journal of Experimental Medicine, vol. 194, no. 11, pp. 16171624, 2001.

[102] K. Leyshon-Sorland, L. Morkrid, and H. E. Rugstad, "Metallothionein: a protein conferring resistance in vitro to tumor necrosis factor," Cancer Research, vol. 53, no. 20, pp. 48744880, 1993.

[103] T. Kimura, N. Itoh, M. Takehara, et al., "Sensitivity of metallothionein-null mice to LPS/D-galactosamine-induced lethality," Biochemical and Biophysical Research Communications, vol. 280, no. 1, pp. 358-362, 2001.

[104] K.-I. Inoue, H. Takano, A. Shimada, et al., "Role of metallothionein in coagulatory disturbance and systemic inflammation induced by lipopolysaccharide in mice," The FASEB Journal, vol. 20, no. 3, pp. 533-535, 2006. 


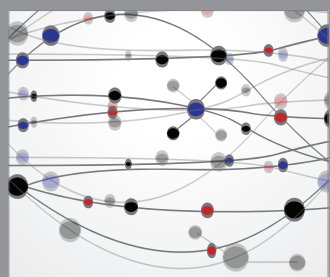

The Scientific World Journal
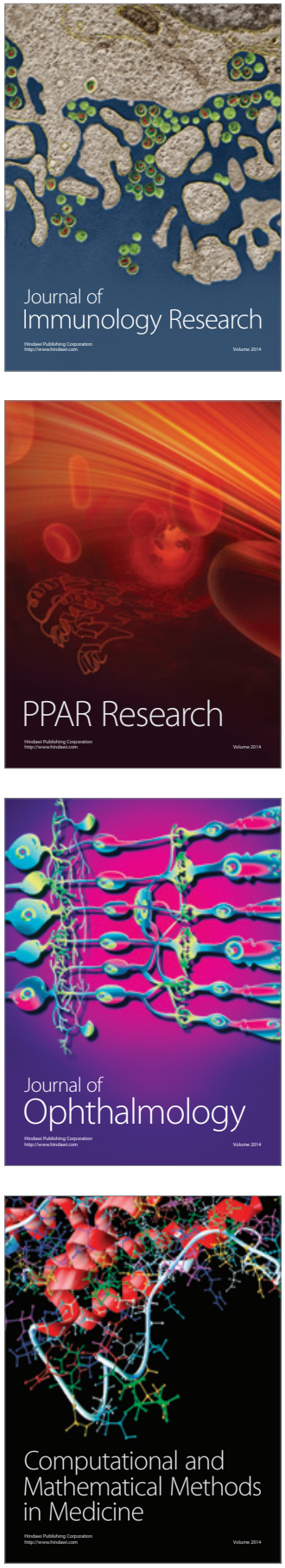

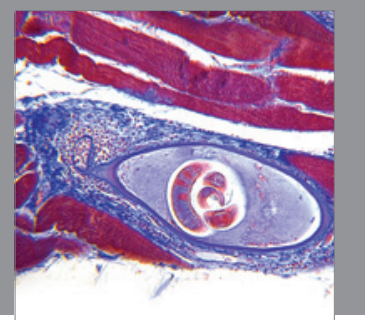

Gastroenterology

Research and Practice
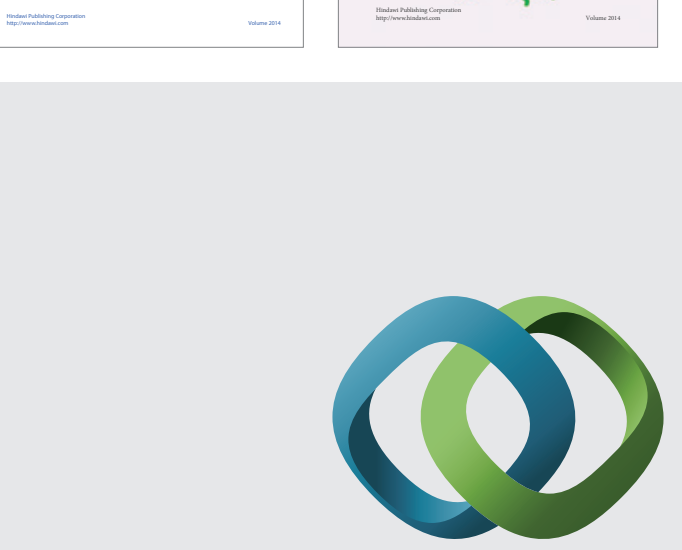

\section{Hindawi}

Submit your manuscripts at

http://www.hindawi.com
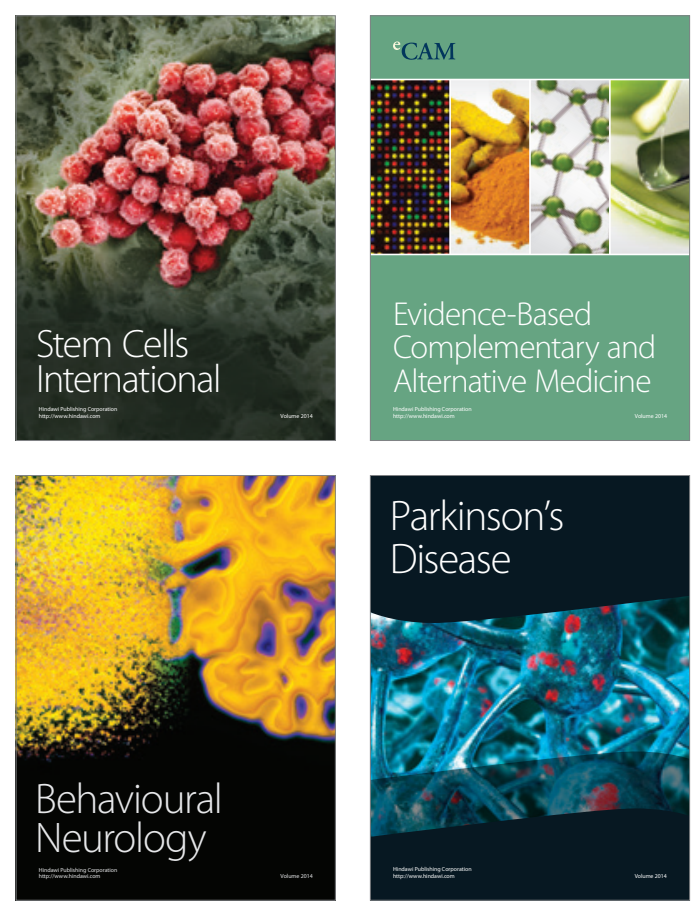

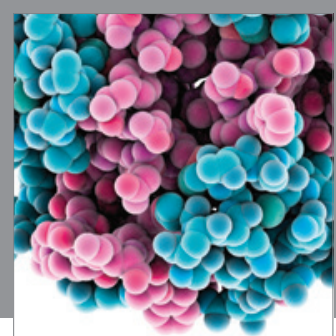

Journal of
Diabetes Research

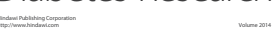

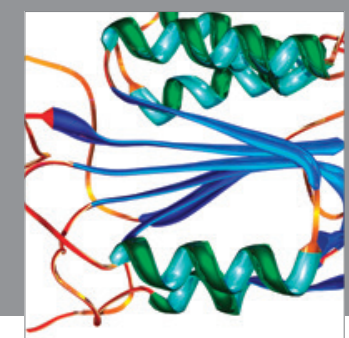

Disease Markers
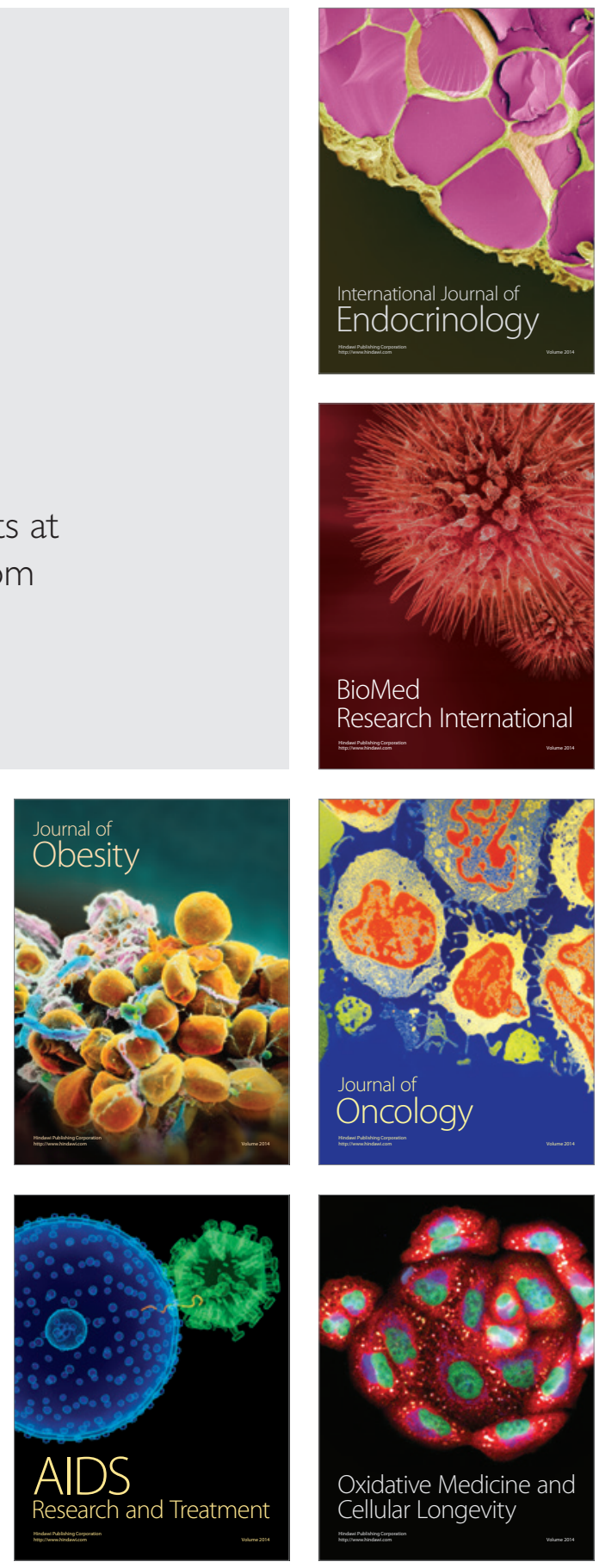